\title{
Mitigation strategy on the uncertainty supply chain of the fisheries sector in small islands, Indonesia
}

\author{
Wellem Anselmus Teniwut ${ }^{a^{*}}$, Syahibul Kahfi Hamid ${ }^{\mathrm{a}}$ and Marvin Mario Makailipessy ${ }^{\mathrm{b}}$
}

${ }^{a}$ Fisheries Agribusiness Study Program, Tual State Fisheries Polytechnic, Indonesia ${ }^{b}$ Fishing Technology Study Program, Tual State Fisheries Polytechnic, Indonesia

\begin{tabular}{l}
\hline C H R O N I C L E \\
\hline Article history: \\
Received May 5, 2020 \\
Received in revised format June \\
8,2020 \\
Accepted August 82020 \\
Available online \\
August 8 2020 \\
\hline Keywords: \\
Uncertainty \\
Supply chain \\
Naïve bayes \\
HOR \\
Fisheries
\end{tabular}

\begin{abstract}
A B S T R A C T
The geographical constrain of small islands associated with fisheries commodities, is due to the lack of insufficient infrastructure and socio-economy characteristics, in addition to the nature of fisheries commodities where the durability and inconsistency of quality and quantity of the particular region become very vulnerable to uncertainty of supply chain. This study aims to formulate a strategy to mitigate the existing effect of uncertainty supply chain in Southeast Maluku Regency. The data mining approach with naïve bayes was used to determine the clusters of areas with high to low interdependency in villages and sub-districts. In addition, the House of Risk (HOR) was used to identify the cause of risks and provided the most effective and efficient alternative strategy to mitigate the uncertainty of the fisheries' supply chain sector. Data were collected from 28 villages to obtain 322 datasets by using the purposive sampling technique and expert assessment method for the data mining process, and HOR, respectively. The result show that the village location, resources, and fishermen's ability to sell and buy their gear were the main determinant factors of interdependency. Furthermore, there were, at least, three clusters of interdependencies with the integration of a web-based system to help spread information to fishermen and aquaculture farmers. In conclusion, policymakers need to be more adaptable to the use of information technology to efficiently improve the welfare and performance of coastal communities, aside from constantly enhancing the region's infrastructure.
\end{abstract}

(C) 2020 by the authors; license Growing Science, Canada.

\section{Introduction}

In 2016 the fisheries sector of Southeast Maluku Regency contributed to the GRDP (Gross Regional Domestic Product) of $21.43 \%$. It ranked third below government expenditure for wage and travel expenses at $24.08 \%$ as well as the trade and construction sector at $22.94 \%$. However, the current stance of fisheries' contribution to the economy is still below the existing potential. The Arufura Sea, which is one of the largest and richest fish areas globally, is close to this region and consists of high potential for seaweed cultivation and well-known marine tourism across the globe. Therefore, the income generated from the fisheries sector makes it the number one contributor to the community and regional welfare. The value of money generated from the coastal areas in Southeast Maluku Regency was around IDR 243,070,000 per month (Picaulima et al., 2017). This amount is generated in conditions, with limitations to the capabilities and competence of coastal communities, especially the level of mastery and access to technology, without significant contributions from local governments (Teniwut \& Teniwut, 2018). Conversely, an empirical study conducted by Teniwut et al. (2019) and Teniwut (2016), showed that the potential of fisheries in Southeast Maluku Regency is abundant.

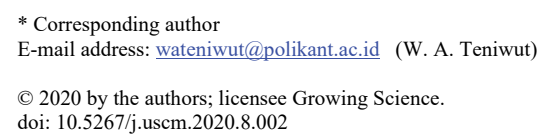


The Southeast Maluku Regency Government has tried to take concrete actions by providing assistance and training programs. However, in reality, this was wrongly targeted because the local government does not carry out good framework and references to provide adequate assistance (Teniwut \& Kabalmay, 2015). Some local government programs are not properly implemented, for instance, the seaweed processing plants which have failed in production. The fishing gear assistance programs are also shown by research from Teniwut and Teniwut, (2018) on government ability to implement central and regional roles that do not have a real impact on the fisheries sector. The ineffectiveness of these local programs was due to many factors that were not considered, such as the socio-economic conditions of the community (Teniwut et al. 2017a), technological capability, and mastery (Teniwut \& Teniwut, 2018), water conditions (Hamid et al., 2017), infrastructure and markets (Teniwut et al., 2017b). Conversely, the demand for the fisheries sector as a driving force of the economy is greater due to the community's geographical and socio-economic conditions. These existing obstacles are currently analyzed by the coastal community all over the world and in archipelagic areas. The nature of fisheries commodities regarding the durability and inconsistency of quality and quantity supplied has geographical constraints. Therefore, the lack of insufficient infrastructure and socio-economy characteristics makes the region vulnerable to the uncertainty of the supply chain. The activities carried out in the fisheries sector are related to the location of producers, and processing plants. Furthermore, the distribution process is closely related to the transported equipment, such as natural disasters and seasonal factors. According to Harris et al. (2014), the agriculture sector includes many factors that make high uncertainty supply chain in the fisheries sector. Meanwhile, the high level of dependence on the fisheries sector as the economic driver of the poor and the main food supply were critical activities that caused the supply chain to be smooth (Barrett et al., 1999; Hinrichs \& Lyson, 2008).

The villages in Southeast Maluku Regency are traditionally dependent on one another due to the use of a customary system in the management of marine resources, also known as the "petuanan laut" and "pela" relationship (Hamid et al., 2020). In addition, the uneven distribution of wealth and welfare between villages leads to high levels of inter-village dependency, which has contributed to the uncertainty of the fisheries supply chain. The condition of the archipelago region is associated with the varying distance between villages. Furthermore, big cities in the region, utilize a spatial approach to provide advantages (Teniwut et al., 2019; Watson et al., 2010; Balaguer et al., 2011; Fernandes and Pinhho, 2017; Vroom et al. 2010; Specht, 2007; Arévalo and Fernández-Palacios. 2003). Spatial analysis is more powerful when combined with other analytical methods, such as data mining, which is used to obtain useful information (Hand, 2007). This capability provides useful analytical results in accordance with the archipelago's geographical conditions, when combined with a spatial approach. The use of data mining with spatial has been widely used in crime mapping (Wang et al., 2013), construction (Shirowzhan et al., 2020), meteorology (Gholami et al., 2020), health sector (Kao et al., 2017), land-subsidence (Pourghasemi \& Saravi, 2019), oil industry (Gongquan \& Keyan 2011), agriculture (Silva et al., 2016), and fisheries sector (Teniwut et al., 2019). The research conducted by using two or more analytical approaches obtained robust and compelling results that are comprehensive and also known as multi-methodology. Mingers (2006/2010) combined analytical methods to answer various research questions. However, in this study, the level of interdependency between villages in this region was measured using various data mining approaches. It was also visualized with spatial analytics to determine the cause of supply chain as well as the uncertainty risk in the region. Furthermore, the MCDM approach, known as the House of Risk (HOR) introduced by Pujawan and Geraldin (2009), was also utilized in this research. The HOR approach is an adaptation of the QFD used to identify the sources of risks that arise from alternative solutions that are efficient and effective. Many studies have used this method in various fields of fisheries (Teniwut, 2019; Anggrahini et al. 2015), and production (Widiasih et al., 2015; Ma et al., 2018).

Therefore, this research aims to mitigate the risk of uncertainty in the fisheries sector's supply chain in Southeast Maluku Regency. It is divided into two parts with the level of dependency between villages in the supply chain process identified in the first section by using data mining and spatial analytical approaches. Meanwhile, the second section identified the sources and risks inherent the HOR approach to effectively calculate the uncertainty of the supply chain in the fisheries region. This paper is structured into five sections. The first, introduces the topic with the materials and methods presented in the second section. The study results were determined using the data mining and analytical methods in Section 3.1, while the HOR was determined in Section 3.2. Discussions and conclusion were carried out in sections 4 and 5.

\section{Material and Method}

\subsection{Study Location and Data Collection}

Southeast Maluku Regency is located between 50 12'19,427" - 60 06'18,275" South Latitudes and 1320 21'39,082" 133015 ' 31,442" East Longitudes. It is geographically bounded by the Banda, Arafura, and Tual Municipality and Banda Seas in the North, South, West, and East, respectively. Maluku regency consists of 11 subdistricts and 193 villages, with majority located on the coast (Statistic Indonesia, 2020). The fisheries sector, which comprises of captured, aquatic, and processed marine tourism, is the main economic resource of coastal communities. This study selected villages based on those that are highly dependent on the fisheries sector, with the geographical conditions used to determine the percentage of villages per sub-district. A total of 28 villages were scattered in 11 sub-districts, with data obtained from 359 respondents. Approximately 322 data were valid for the mining purposes, while the expert's assessments with cross-validation were used to determine the HOR, as shown in Fig. 1. 

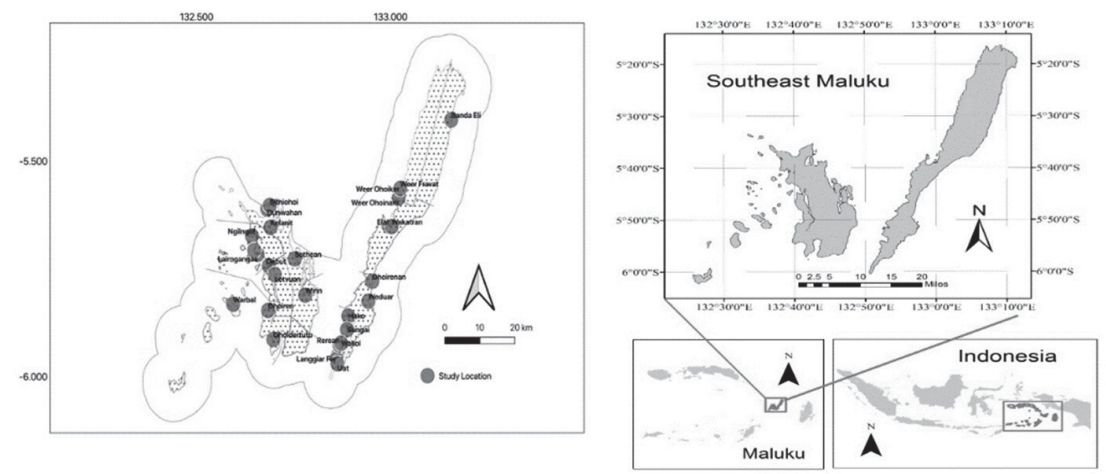

Fig. 1. Study Location

\subsection{Analysis Method}

\subsubsection{Nä̈ve Bayes}

The naïve Bayes algorithm is based on the assumption of attribute independence, simplifying the Bayesian model (Zhang, 2005). The NB is one of the most widely used algorithms due to its robustness, therefore, assuming each predictor is conditionally independent, it tends to calculate the probabilities of a particular class (Duda, 1973). The Bayes theorem on the Naïve Bayes algorithm occurs when combining prior and conditional probability to calculate each possible classification (Bramer, 2007). Let T represent data sample with no class, where $R$ is the hypothesis. $P(R / T)$ is the probability $P(R), P(T)$ and $\mathrm{P}(\mathrm{R} \mid \mathrm{T})$ is the posterior representing the confidence in the hypothesis after T. The basic relationship formula of NB is calculated as follows (Catal et al. 2011):

$$
P(R \mid T)=\frac{P(T \mid R) \cdot P(R)}{P(T)}
$$

As for the basic idea of NB theorem is:

$$
P\left(W_{i} \mid T\right)=\frac{P\left(T \mid C_{i}\right) \cdot P\left(C_{i}\right)}{P(X)}
$$

Suppose there is a set of $v$ samples where $S_{i}$ is represented as an $n$-dimensional feature vector $\left\{T_{1}, T_{2}, \ldots, T_{n}\right\}$, $T_{i}$ corresponds to attributes $A_{1}, A_{2}, \ldots A_{n}$, respectively. Furthermore, in $k$ classes of $c_{1}, c_{2}, \ldots, c_{k}$ there are additional unknown data samples of $T$, used to predict the highest conditional probability $P\left(C_{i} \mid T\right)$, where $i=1,2 \ldots, k$. The probability distribution of NB is utilized with the application of a regression problem. However, the NB is not a 'Bayesian' method that analyzes the frequentist interpretation strategy ( $\mathrm{Ng}$ et al., 2014).

\subsubsection{House of Risk}

The House of Risk (HOR) model is an integration of the Failure Modes and Effects Analysis (FMEA) with the Quality Function Deployment (QFD). There are two stages in the method, namely HOR1, which is used to identify the sources and risks that occur and HOR2 used to calculate and choose alternative solutions that are efficient in mitigating the uncertainty associated with the risk of the fisheries supply chain in the region (Pujawan \& Geraldin, 2013). In HOR1, first identify the "risk events" in each of these processes-based on the Plan, Source, Deliver, Make, and Return, as shown in Table 1 (Model Supply Chain Operations Reference). Ei (risk events) showed that the risk was analyzed from a scale from 1 to 5, which represents the largest severity of each event. This was followed by identifying the $\mathrm{Aj}$ and assessing the likelihood of occurrence, as shown in Table 2. It also determines the relationship between risk agent and Rij with a value of $0,1,3$, and 9, which indicates no, low, moderate, and high correlation. The formula for HOR1 is as follows:

$$
A R P_{j}=O_{J} \sum_{i} S_{I} R_{I J}
$$

In HOR2, the analysis started with selecting the highest risk agent which is more than $70 \%$, as shown in Fig. 2. In addition, the risk mitigation is obtained using the Preventive Actions (PAk) as shown in Table 3. The total effectiveness (TEk) is calculated with the following formula:

$$
\mathrm{TEk}=\sum A R P_{j} E_{j k} \forall k \text {. }
$$

The difficultness $(D k)$ in level with Likert or sufficient scale is used to calculate the total ratio effectiveness using the mitigation action and highest rank $\left(R_{k}\right)$ formulas follows:

$E T D k=D_{k} T E_{k}$ 
Table 1

\begin{tabular}{|c|c|c|c|c|}
\hline SCOR & Sub Process & Risk Event & Code & W \\
\hline \multirow{5}{*}{ Plan } & \multirow{3}{*}{$\begin{array}{c}\text { Production } \\
\text { Planning }\end{array}$} & Changes in weather and season & E1 & 5 \\
\hline & & Inconsistent production & E2 & 5 \\
\hline & & Limited and damaged equipment & E3 & 7 \\
\hline & \multirow{2}{*}{$\begin{array}{l}\text { Inventory } \\
\text { Planning }\end{array}$} & improper inventory system & E4 & 9 \\
\hline & & Lack of demand and market information inside and outside the region & E5 & 9 \\
\hline \multirow{2}{*}{ Source } & \multirow{2}{*}{ Distribution } & Very limited buyers & E6 & 6 \\
\hline & & Inconsistent supplier performance & E7 & 5 \\
\hline \multirow{3}{*}{ Make } & \multirow{4}{*}{ Production } & Inconsistent results due to pests & E8 & 7 \\
\hline & & The catching range is not optimal not comparable with the equipment & E9 & 9 \\
\hline & & Forced to premature harvest & E10 & 7 \\
\hline \multirow{3}{*}{ Deliver } & & Too far distance between the market village and the supplier & E11 & 7 \\
\hline & \multirow[t]{2}{*}{ Delivery } & Limited transportation & E12 & 9 \\
\hline & & Shipping costs are quite high & E13 & 7 \\
\hline \multirow{2}{*}{ Return } & \multirow{2}{*}{ Return Policy } & There is no product return policy & E14 & 7 \\
\hline & & There is no refund policy when there is a discrepancy in the order and damage & E15 & 9 \\
\hline
\end{tabular}

Table 2

Risk Agents

\begin{tabular}{|c|c|c|}
\hline Risk Agent & Occurrence & Code \\
\hline The instability of demand & 9 & A1 \\
\hline Low inter-region connectivity & 9 & A2 \\
\hline Lack of accuracy of local government aid & 5 & A3 \\
\hline Availability of quality seeds & 5 & A4 \\
\hline Season changes & 7 & A5 \\
\hline Science and technology not adequately adapted & 9 & A6 \\
\hline Conflict between villages & 4 & A7 \\
\hline Dependent on the local distributor & 5 & A8 \\
\hline Lack of managerial ability & 9 & A9 \\
\hline Uncompetitive selling prices & 7 & A10 \\
\hline Insignificant impact of NGOs, Research Institutions and Universities & 3 & A11 \\
\hline The geographical location of each village & 7 & A12 \\
\hline
\end{tabular}

Table 3

Preventive Actions

\begin{tabular}{ll} 
Code & Preventive actions \\
\hline PA1 & Build markets per cluster based on geographical location \\
PA2 & Build an integrated inventory per area \\
PA3 & Increase transportation access between regions \\
PA4 & Build web-based integrated systems to update market and price information consistently \\
PA5 & Build BUMD such as Regional owned-enterprise to ensure consistent demand for raw fishery products \\
PA6 & Local Governments assist in searching for buyers outside the region. \\
\hline
\end{tabular}

\section{Result}

\subsection{Naïve Bayes and spatial analysis}

The comparison results associated with the performance levels of several data mining algorithms are shown in Table 4. Furthermore, the result shows that the Naive Bayes had better indicators than other methods with a higher level of accuracy at $81.8 \%$, compared to four other methods, namely deep learning $(78.1 \%)$, logistics regression $(77.1 \%)$, support vector machines $(75.9 \%)$, and generalized linear models $(75.9 \%)$. In addition, several other indicators show the same results.

Table 4

Performance Indicator Comparison

\begin{tabular}{|c|c|c|c|c|c|}
\hline \multirow{2}{*}{ Criteria } & \multicolumn{5}{|c|}{ Algorithm } \\
\hline & NB & DL & LR & SVM & GLM \\
\hline Accuracy & $81.8 \%$ & $78.1 \%$ & $77.1 \%$ & $75.9 \%$ & $75.9 \%$ \\
\hline F Measure & $74 / 6 \%$ & $67.1 \%$ & $62.7 \%$ & $61.0 \%$ & $59.9 \%$ \\
\hline Sensitivity & $76.5 \%$ & $66.8 \%$ & $54.3 \%$ & $47.0 \%$ & $46.6 \%$ \\
\hline Classification Error & $18.2 \%$ & $21.9 \%$ & $22.9 \%$ & $24.1 \%$ & $24.1 \%$ \\
\hline
\end{tabular}

*NB (naïve Bayes); DL (deep learning); LR (logistic regression); SVM (support vector machine); GLM (generalized linear model)

The prediction results with naïve Bayes are used to examine the dependence level of villages in this region, as shown in Table 5. However, the potential of marine resources owned by the market value is $0.114,0.079$, and 0.064 , which are used to significantly determine whether a village is dependent or not in relation to the fisheries sector. The prediction results obtained from naïve Bayes is shown in Fig. 2, where the heatmap illustrates the distribution of clusters in villages that were highly dependent on fishing activities. It can be seen that the villages in Kei Besar Selatan and Barat sub-districts are the regions with the high and moderate levels of dependency, respectively. 
Table 5

Weight determinant factors of villages in Southeast Maluku Regency

\begin{tabular}{clc}
\hline Rank & Attribute & Weight \\
\hline 1 & Location relatively too big cities and other villages & 0.114 \\
2 & Village marine resources & 0.079 \\
3 & Where the community sell their product & 0.064 \\
4 & Duration of community work on the fisheries sector & 0.057 \\
5 & Role on fisheries activities & 0.026 \\
6 & Relationship with the community within and outside the village & 0.024 \\
7 & Where community buy their fisheries equipment & 0.010 \\
8 & Income & 0.004 \\
\hline
\end{tabular}

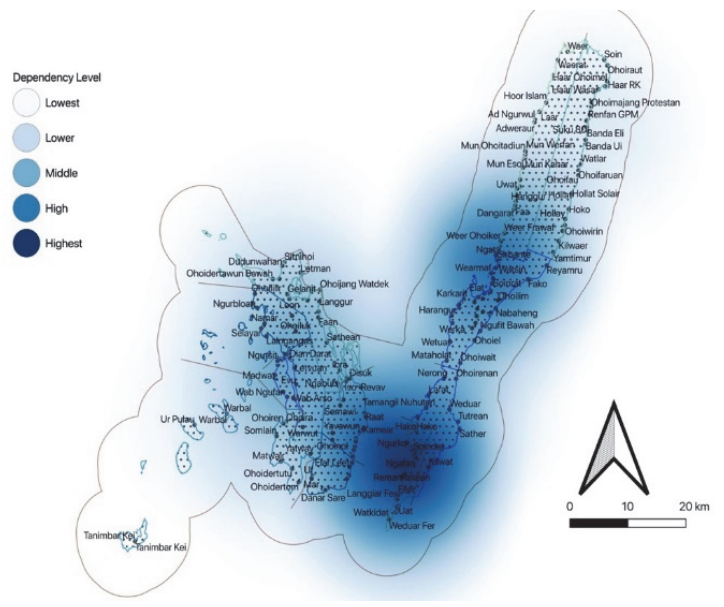

Fig. 2. Heatmap of the dependency area of each village in Southeast Maluku Regency

\subsection{House of Risk}

Based on the results of the HOR obtained in Table 6, the highest ARP value for the risk agents was A6 (4293), followed by A9 (4239), A12 (2373), A2 (2349), A1 (2160), A5 (1071), A4 (600), A11 (396), A8 (394), A3 (345) and A7 (268). Furthermore, the Pareto diagram in Fig. 3 shows that a total of five risk agents contributed to $77 \%$ of all sources with the uncertainty of the fishery supply chains between villages in this region, namely A6, A9, A12, A2, and A1. Table 7 shows the results of HOR2, which were alternative policies and steps taken by the regional government with a significant role in handling and mitigating the uncertainty of the supply chain in the region. The result showed that the highest alternative ETD value was PA4, with integrated web-based systems to update market and price information consistently followed by PA6, PA2, PA5, PA3, and PA1. The selected alternative policy is financially feasible and rational to carry out to avoid burdening the local governments, with the ability to mitigate the risk of supply chain uncertainties fisheries in this region.

Table 6

HOR 1

\begin{tabular}{|c|c|c|c|c|c|c|c|c|c|c|c|c|c|c|c|}
\hline \multicolumn{16}{|c|}{ Risk Agents } \\
\hline $\begin{array}{l}\text { Business } \\
\text { Process }\end{array}$ & $\begin{array}{c}\text { Risk } \\
\text { Events }\end{array}$ & A1 & $\mathrm{A} 2$ & A3 & A4 & A5 & A6 & A7 & A8 & A9 & A10 & A11 & A12 & $\begin{array}{c}\text { Severity of Risk } \\
\text { Events }\end{array}$ & Value \\
\hline \multirow[t]{5}{*}{ Plan } & E1 & & & & & 9 & & 1 & & & & & 3 & $\mathrm{~S} 1$ & 5 \\
\hline & E2 & & & & 3 & 9 & 9 & & & 9 & 3 & 3 & & $\mathrm{~S} 2$ & 5 \\
\hline & E3 & & & 9 & 3 & & 9 & & & 3 & & 3 & 3 & S3 & 7 \\
\hline & E4 & & & 3 & & & 9 & & & 9 & & 3 & & S4 & 9 \\
\hline & E5 & 9 & 3 & 9 & & & 3 & & & & & 3 & 9 & S5 & 9 \\
\hline \multirow[t]{2}{*}{ Source } & E6 & 9 & 9 & & & & 9 & & 9 & 3 & 3 & & & S6 & 6 \\
\hline & E7 & 3 & & & & 9 & & & & 3 & 3 & & 3 & S7 & 5 \\
\hline \multirow[t]{3}{*}{ Make } & E8 & 3 & & 3 & 9 & & 9 & & & 9 & & 3 & & S8 & 7 \\
\hline & E9 & & & & & & 9 & & & 3 & & & & S9 & 9 \\
\hline & E10 & & & & 3 & & 9 & 1 & 3 & 9 & 9 & 3 & & $\mathrm{~S} 10$ & 7 \\
\hline \multirow[t]{3}{*}{ Deliver } & E11 & 3 & 9 & & & & & 3 & 3 & 3 & 3 & & 9 & S11 & 7 \\
\hline & E12 & 3 & 9 & 9 & & & & 3 & 3 & & 3 & & 9 & $\mathrm{~S} 12$ & 9 \\
\hline & E13 & 3 & 9 & 3 & & & & 1 & 3 & & 3 & & 9 & $\mathrm{~S} 13$ & 7 \\
\hline \multirow[t]{2}{*}{ Return } & E14 & & & & & & & & 1 & 9 & 3 & & & $\mathrm{~S} 14$ & 7 \\
\hline & E15 & & & & & & & & 3 & 9 & 3 & & & $\mathrm{~S} 15$ & 9 \\
\hline Occurrence & & 9 & 9 & 5 & 5 & 7 & 9 & 4 & 5 & 9 & 7 & 3 & 7 & & \\
\hline ARP & & 216 & 2349 & 345 & 600 & 107 & 429 & 268 & 394 & 423 & 159 & 396 & 237 & & \\
\hline Priority & & 5 & 4 & 11 & 8 & 7 & 1 & 12 & 10 & 2 & 6 & 9 & 3 & & \\
\hline
\end{tabular}




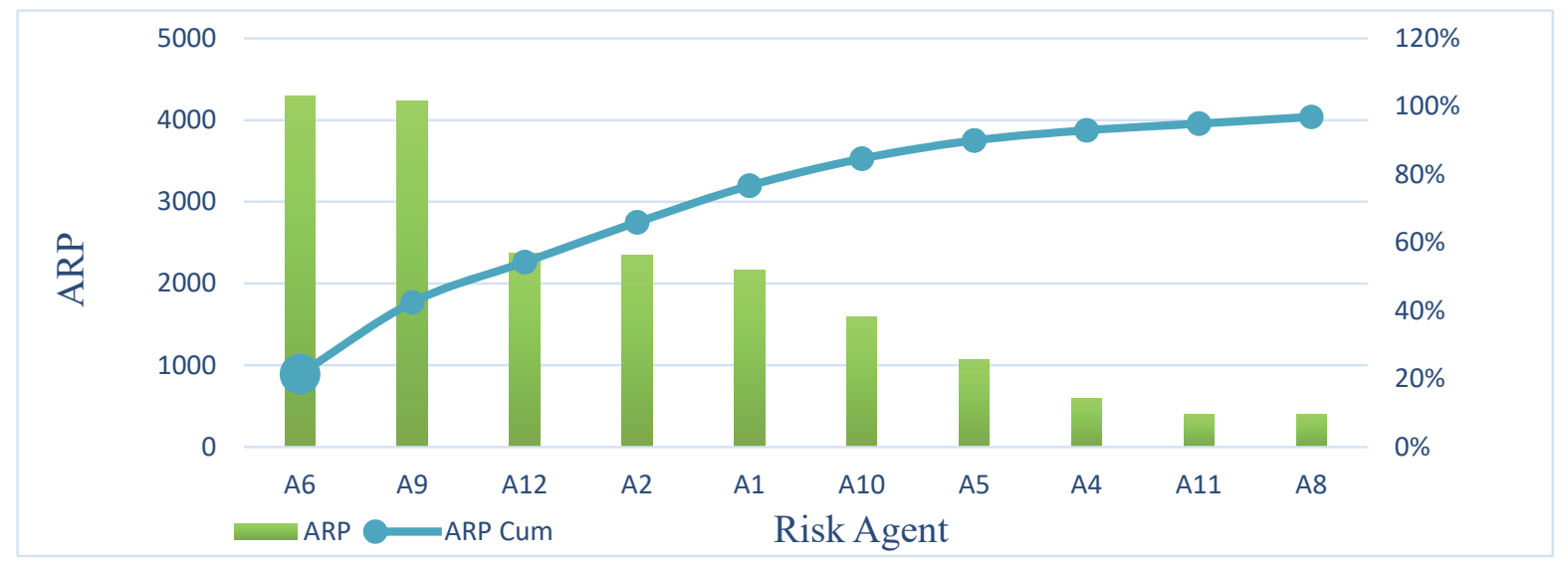

Table 7

Fig. 3. Diagram Pareto HOR1

\begin{tabular}{|c|c|c|c|c|c|c|c|c|}
\hline Risk Agent & PA1 & PA2 & PA3 & PA4 & PA5 & PA6 & ARP & Code \\
\hline A6 & & 9 & & 9 & 9 & & 4293 & ARP6 \\
\hline A9 & & 9 & 3 & 9 & 9 & 9 & 4239 & ARP8 \\
\hline A 12 & 9 & 3 & 9 & 9 & & 9 & 2373 & ARP10 \\
\hline $\mathrm{A} 2$ & 9 & 3 & 9 & 9 & 3 & 9 & 2349 & ARP9 \\
\hline A1 & 9 & & 9 & 9 & 9 & 9 & 2160 & ARP2 \\
\hline $\mathrm{TE}$ & 61.938 & 90.954 & 74.655 & 138.726 & 86.004 & 100.089 & & \\
\hline $\mathrm{D}$ & 5 & 4 & 5 & 3 & 5 & 3 & & \\
\hline ETD & 12.388 & 22.739 & 14.931 & 46.242 & 17.201 & 33.363 & & \\
\hline $\mathrm{R}$ & 6 & 3 & 5 & 1 & 4 & 2 & & \\
\hline
\end{tabular}

\section{Discussion}

This region comprises of the archipelago with a wealth of high marine resources. However, not all villagers in this region take the fisheries business as a regular source of income, despite the fact that it is one of the economy's backbones, especially in coastal communities. The high rate of fish consumption for households and manufacturing industries is very important for the local fisheries sector to have a smooth chain level. The infrastructures have experienced good communication in the transportation of other supporting instructors in the region. In addition, the existing geographical conditions still experience difficulties in accessing fast and smooth transportation in the distribution of fishery products. Therefore, the socio-economic characteristics of coastal communities in this region tend to overcome the risk of uncertainty in the supply chain of fisheries. The study obtained two main clusters that are highly dependent on neighboring villages related to fishing businesses. These two clusters are distributed in four subdistricts, with the first cluster region spread across Kei Besar Selatan Barat. These districts have a dependency on their surrounding areas due to the location at the edge of Kei Besar Island with potential and residents that regularly carry out fisheries activities. This area is quite far from buyers' and sellers' location, with the residents experiencing difficulty in buying seeds for quality seaweed cultivation and distributes fishery products that are obtained smoothly and adequately. The second cluster in Kei Besar and Utara Barat Subdistricts have access to transportation, which is better than the first area. However, this cluster comprises of a limited number of buyers in the surrounding area. This is a similar problem also faced by the second cluster and used to improve coastal communities' welfare. Therefore, it is better to distribute the fishery products obtained in the market and minimize the acquisition costs of equipment that is carried out in an effort to attract buyers and sellers. Therefore, in addition to increasing the income of coastal communities, it also minimizes the risk of supply chain uncertainty in this region. The main causes of the high level of dependence on coastal communities and the risk of supply chain uncertainty are science and technology. These two factors are influential and have not been properly implemented in carrying out business activities in almost all regions in Southeast Maluku Regency. They are also used to schedule fisheries activities that are not appropriately carried out, which cause special harvests for aquaculture in accordance with current demand. The location of captured fishes is close to the village, which tends to be inconsistent, due to the use of equipment and technology not adjusted to the standards. The ability to adopt technology and good knowledge in conducting fisheries is still not maximized in addition to the low managerial ability, which causes the sustainability of the business owned to be quite disturbed. Presently, the geographical location and infrastructure are limited to the source of problems faced by all sectors in the region. However, fisheries businesses emphasize the importance of a consistent market both inside and outside the region. This plays a huge potential to fisheries resources with consistent market force coastal communities to improve their performance. The limited number of buyers makes the supply of fisheries commodities very inconsistent, in a fairly limited amount of time. The results of the study offer six alternative policies in accordance with the empirical conditions of this region. Out of the six alternative policies, the study found that local government integrated web-based integrated systems to update market and price information consistently. This helps to 
determine the markets outside the region and contributes to building an integrated inventory per area. According to Taylor and Fearne (2009), information is essential for the food market and fisheries. Allievi et al. (2015) stated that the importance of efficiency in all strategy is also related to technology. Therefore web-based information systems are used to meet the criteria. Although this study proposed a long-term permanent solution for the fisheries sector and coastal communities, a regional owned-enterprise is built using BUMD to ensure consistent demand for raw fishery products. This tends to act as a guide for coastal communities to be more consistent in conducting fisheries business, and increasing the supply of quality fisheries.

\section{Conclusion}

In conclusion, this study has utilized the multi-methodology approach to mitigate the risk associated with the fisheries sector's supply chain uncertainty in Southeast Maluku District. It was divided into two parts with the data mining approach and naïve Bayes used in the first section to predict clusters, which are vulnerable points due to the high dependency of these villages on neighboring and large cities. The Naive Bayes approach used also found determinants of the level of dependency and uncertainty in the supply chain of the fisheries sector in the region. Furthermore, the villages' geographical location is an important factor used to determine the dependency of clusters in this region. The closer the sellers and buyers are to the fishery equipment, the lower the uncertainty associated with the supply chain risk. The second method approach used is the MCDM House of Risk (HOR) approach with mitigation for the risk of uncertainty that is financially efficient for regional governments. Web-based integrated systems are built to update market and price information consistently and act as an alternative to mitigating the fisheries supply chains in the region. However, it is more efficient compared to other available alternatives.

\section{Acknowledgment}

The authors are grateful to The Directorate of Research and Community Service, Ministry of Research and Technology/National Research and Innovation Agency (Indonesia) Republic of Indonesia, for funding this research under PDUPT 2020 scheme.

\section{References}

Allievi, F., Vinnari, M., \& Luukkanen, J. (2015). Meat consumption and production-analysis of efficiency, sufficiency, and consistency of global trends. Journal of Cleaner Production, 92, 142-151.

Anggrahini, D., Karningsih, P. D., \& Sulistiyono, M. (2015). Managing quality risk in a frozen shrimp supply chain: a case study. Procedia Manufacturing, 4, 252-260.

Arévalo, J. R., \& Fernández-Palacios, J. M. (2003). Spatial patterns of trees and juveniles in a laurel forest of Tenerife, Canary Islands. Plant Ecology, 165(1), 1-10.

Barrett, H. R., Ilbery, B. W., Brown, A. W., \& Binns, T. (1999). Globalization and the changing networks of food supply: the importation of fresh horticultural produce from Kenya into the UK. Transactions of the Institute of British Geographers, 24(2), 159-174.

Balaguer, P., Diedrich, A., Sardá, R., Fuster, M., Cañellas, B., \& Tintoré, J. (2011). Spatial analysis of recreational boating as a first key step for marine spatial planning in Mallorca (Balearic Islands, Spain). Ocean \& Coastal Management, 54(3), 241-249.

Bramer, M. (2007). Principles of data mining (Vol. 180). London: Springer.

Catal, C., Sevim, U., \& Diri, B. (2011). Practical development of an Eclipse-based software fault prediction tool using Naive Bayes algorithm. Expert Systems with Applications, 38(3), 2347-2353.

Duda, R. O., \& Hart, P. E. (1973). Bayes decision theory. Chapter, 2, 10-43.

Fernandes, R., \& Pinho, P. (2017). The distinctive nature of spatial development on small islands. Progress in Planning, 112, 1-18.

Gholami, H., Mohamadifar, A., \& Collins, A. L. (2020). Spatial mapping of the provenance of storm dust: Application of data mining and ensemble modelling. Atmospheric Research, 233, 104716.

Gongquan, L. I., \& Keyan, X. I. A. O. (2011). Spatial data-mining technology assisting in petroleum reservoir modeling. Procedia Environmental Sciences, 11, 1334-1338.

Hamid, S. K., Teniwut, W. A., Teniwut, R. M., Rahantoknam, M. A., Hasyim, C. L., \& Hungan, M. (2017, October). The Support of MPA (Marine Protected Area) in Coral Triangle Area: Evidence from Kei Islands, Indonesia. In IOP Conference Series: Earth and Environmental Science (Vol. 89, No. 1, p. 012025). IOP Publishing

Hamid, S. K., Teniwut, W. A., Teniwut, R. M. K., Renhoran, M., \& Arifin, D. (2020). Using data mining and spatial analysis for mapping the economic value and resources of indigenous communal sea in Indonesia: Kei Islands. $A A C L$ Bioflux, 13(1).

Hand, D. J. (2007). Principles of data mining. Drug safety, 30(7), 621-622.

Harris, D. R., \& Fuller, D. Q. (2014). Agriculture: definition and overview. Encyclopedia of global archaeology, 104-113.

Hinrichs, C. C., \& Lyson, T. A. (Eds.). (2007). Remaking the North American food system: Strategies for sustainability. U of Nebraska Press.

Kao, J. H., Chan, T. C., Lai, F., Lin, B. C., Sun, W. Z., Chang, K. W., ... \& Lin, J. W. (2017). Spatial analysis and data mining techniques for identifying risk factors of out-of-hospital cardiac arrest. International Journal of Information Management, 37(1), 1528-1538. 
Ma, H. L., \& Wong, W. H. C. (2018). A fuzzy-based House of Risk assessment method for manufacturers in global supply chains. Industrial Management \& Data Systems.

Mingers, J. (2010). Multimethodology. Wiley Encyclopedia of Operations Research and Management Science.

Mingers, J. (2006). A critique of statistical modelling in management science from a critical realist perspective: its role within multi-methodology. Journal of the Operational Research Society, 57(2), 202-219.

Ng, S. S., Xing, Y., \& Tsui, K. L. (2014). A naive Bayes model for robust remaining useful life prediction of lithium-ion battery. Applied Energy, 118, 114-123.

Picaulima, S., Teniwut, W. A., Kahfi, S., Teniwut, R. M., Susanti, I. I. D. A. R., Hungan, M., ... \& Ngabalin, A. M. (2017, October). Mapping Marine Resources Utilization Based on Seascapes Area: A Study on Gender Comparison. In IOP Conference Series: Earth and Environmental Science (Vol. 89, No. 1, p. 012027). IOP Publishing.

Pourghasemi, H. R., \& Saravi, M. M. (2019). Land-Subsidence Spatial Modeling Using the Random Forest Data-Mining Technique. In Spatial Modeling in GIS and R for Earth and Environmental Sciences (pp. 147-159). Elsevier.

Pujawan, I. N., \& Geraldin, L. H. (2009). House of risk: a model for proactive supply chain risk management. Business Process Management Journal.

Silva, L. A. E., Siqueira, M. F., dos Santos Pinto, F., Barros, F. S. M., Zimbrão, G., \& Souza, J. M. (2016). Applying data mining techniques for spatial distribution analysis of plant species co-occurrences. Expert Systems with Applications, 43, $250-260$

Specht, J. (2007). Small islands in the big picture: The formative period of Lapita in the Bismarck Archipelago. Oceanic Explorations.

Taylor, D. H., \& Fearne, A. (2009). Demand management in fresh food value chains: a framework for analysis and improvement. Supply Chain Management: An International Journal.

Teniwut, W. A., \& Kabalmay, J. (2015). Emprirical study on evaluation of seaweed cultivation in southeast Maluku. In Prosiding Seminar Ilmiah Tahunan (SIT) Ke-2 Politeknik Perikanan Negeri Tual (Vol. 26, pp. 55-60).

Teniwut, W. A., \& Teniwut, R. M. (2018). Minimizing the instability of seaweed cultivation productivity on rural coastal area: a case study from Indonesia. Aquaculture, Aquarium, Conservation \& Legislation, 11(1), 259-271.

Teniwut, W. A. (2016). For sustainable revenue of fisheries sector in small islands: evidence of Maluku, Indonesia. Aquaculture, Aquarium, Conservation \& Legislation-International Journal of the Bioflux Society (AACL Bioflux), 9(3).

Teniwut, W. A., Teniwut, Y. K., Teniwut, R. M., \& Hasyim, C. L. (2017a). Family vs Village-Based: Intangible View on the Sustainable of Seaweed Farming. In IOP Conference Series: Earth and Environmental Science (Vol. 89, No. 1, p. 012021). IOP Publishing.

Teniwut, W. A., Betaubun, K. D., \& Djatna, T. (2017b). A conceptual mitigation model for asymmetric information of supply chain in seaweed cultivation. In IOP Conference Series: Earth and Environmental Science (Vol. 89, No. 1, p. 012022). IOP Publishing.Harris, D. R., \& Fuller, D. Q. (2014). Agriculture: definition and overview. Encyclopedia of global archaeology, 104-113.

Teniwut, W., Hamid, S., \& Makailipessy, M. (2019). Selecting top fisheries sub-sector in each sub-district for sustainable development of archipelagic region in Indonesia: A hybrid fuzzy-MCDM approach. Decision Science Letters, 8(4), 39341.

Teniwut, W., Marimin, M., \& Djatna, T. (2019). GIS-Based multi-criteria decision making model for site selection of seaweed farming information centre: A lesson from small islands, Indonesia. Decision Science Letters, 8(2), $137-150$.

Shirowzhan, S., Lim, S., Trinder, J., Li, H., \& Sepasgozar, S. M. E. (2020). Data mining for recognition of spatial distribution patterns of building heights using airborne lidar data. Advanced Engineering Informatics, 43, 101033.

Statistic Indonesia. (2020). Maluku Regency in Figures. Statistic of Maluku Tenggara regency. Langgur, Indonesia.

Vroom, P. S., Musburger, C. A., Cooper, S. W., Maragos, J. E., Page-Albins, K. N., \& Timmers, M. A. (2010). Marine biological community baselines in unimpacted tropical ecosystems: spatial and temporal analysis of reefs at Howland and Baker Islands. Biodiversity and Conservation, 19(3), 797-812.

Wang, D., Ding, W., Lo, H., Stepinski, T., Salazar, J., \& Morabito, M. (2013). Crime hotspot mapping using the crime related factors - a spatial data mining approach. Applied intelligence, 39(4), 772-781.

Watson, J., Trueman, M., Tufet, M., Henderson, S., \& Atkinson, R. (2010). Mapping terrestrial anthropogenic degradation on the inhabited islands of the Galapagos Archipelago. Oryx, 44(1), 79-82.

Widiasih, W., Karningsih, P. D., \& Ciptomulyono, U. (2015). Development of integrated model for managing risk in lean manufacturing implementation: a case study in an Indonesian manufacturing company. Procedia Manufacturing, 4, $282-290$

Zhang, H. (2005). Exploring conditions for the optimality of naive Bayes. International Journal of Pattern Recognition and Artificial Intelligence, 19(02), 183-198.

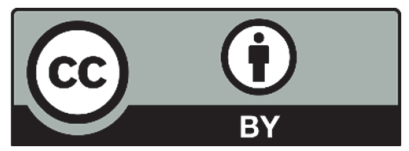

(C) 2020 by the authors; licensee Growing Science, Canada. This is an open access article distributed under the terms and conditions of the Creative Commons Attribution (CC-BY) license (http://creativecommons.org/licenses/by/4.0/). 